\title{
Can E-Commerce Adoption Improve SME's Performance? (Case Studies on Micro, Small and Medium Enterprises with Gojek Services in Indonesia)
}

\author{
Nurlinda $^{1}$, Ilham Hidayah Napitupulu ${ }^{2}$, Wardayani ${ }^{3}$, Azlina $^{4}$, Arie Andina ${ }^{5}$, Almira Keumala \\ Ulfah $^{6}$, Supriyanto ${ }^{7}$ \\ \{nurlinda@polmed.ac.id ${ }^{1}$, ilhamhasan77@yahoo.com² ${ }^{2}$ cici_wardayani@yahoo.ac.id ${ }^{3}$, \\ azlinazto@gmail.com ${ }^{4}$, arie.andina@gmail.com ${ }^{5}$, almirakeumalaulfah@gmail.com ${ }^{6}$, \\ faiziqameira@gmail.com $\left.{ }^{7}\right\}$ \\ ${ }^{1,2}$ Politeknik Negeri Medan, Medan, Indonesia \\ ${ }^{3}$ Sekolah Tinggi Ilmu Manajemen Sukma, Medan, Indonesia \\ 4,5,6 Politeknik Kutaraja, Banda Aceh, Indonesia \\ ${ }^{7}$ Politeknik LP3I Medan, Medan, Indonesia
}

\begin{abstract}
This study aims to see whether organizational readiness, technology readiness, external environment influences e-commerce adoption, and also aims to see whether ecommerce adoption plays a role in improving performance in small, micro and medium enterprises in Medan City. This research is a quantitative research using primary data collected through questionnaire surveys. The sample technique uses random sampling, with 222 samples. The analytical method uses descriptive method with multiple linear regression statistical analysis. Hypothesis testing using t-test, as well as F test with a significant level of $5 \%$. The results of the study found that organizational readiness, technology readiness, external environment, e-commerce adoption simultaneously had a significant positive effect on financial performance. While partially the organizational readiness and technology readiness have a significant positive effect while the external environment has a positive and insignificant influence on e-commerce adoption, and ecommerce adoption has a significant positive effect on financial performance.
\end{abstract}

Keywords: SME’S, E-Commerce, Sales Improve, on line business

\section{Introduction}

Shifting consumer behavior from traditional shopping to online shopping is a challenge for the company. Changes in perceptions of ease of transactions turned out to be the main elements influencing consumer attitudes in changing shopping behavior [1]. One solution that can be used by companies is the use of information technology development, especially the use of online technology through online businesses using e-Commerce. The importance of eCommerce is not only seen from the ease, efficiency of time, effort and cost being the main value, especially for Micro, Small and Medium Enterprises (MSMEs). MSMEs are concentrated in the trade, food, food processing, textile and garment, wood and wood products, and mineral and culinary production sectors. Culinary several years later was included as one of the creative industry sub-sectors in Indonesia so that Indonesia adhered to 15 creative industry sub-sectors [2]. 
Research conducted that perceived benefits, technological readiness, owner's innovation, information capability and technology (IT) owners and the experience of IT owners are the determining factors influencing Indonesian SMEs in adopting e-commerce [3], the other research found that SMEs at a higher level of experience of e-commerce adoption experience provide e-commerce benefits that are greater than those at other adoption levels [4]. Other research found three factors in the adoption of e-commerce consisted of technological readiness factors [2] [5] [6][7][8], external factors of the company [2] and internal factors of the company [2], Several different studies were conducted to examine the factors that influence e-Commerce adoption such as perceived barriers, good support (management support), organizational readiness, competitor pressure. The other factors is competitor pressures that influence e-commerce adoption in MSMEs [9] [10]. Factors of organizational readiness affect e-commerce adoption [9], but other research find that organizational readiness has no effect [10][7]. Factors (perceived barriers) have no effect on e-commerce [9], but the perceived benefits have a positive effect on the adoption of e-commerce in MSMEs [10]. Supporting factors of management affect the adoption of e-commerce in MSMEs [9], while the strategic orientation of family business has a moderating influence between external pressure, organizational readiness and perceived benefits [10]. The use of online technology in e-commerce applications will generally improve performance [11] [12]. The performance in question is related to financial performance where one of them is an increase in profits through increased sales and ultimately the welfare of the community will increase along with business development. The result of several studies indicate that organizational readiness influences on e-commerce adoption [15] [16] [17] [4] [18][19], but several other studies show the opposite [7][20]. Related to the influence of technology readiness on e-commerce adoption shows that there is an influence betweet technology readiness on e-commerce adoption [12][7][21] [22]. The influence of the external environmental on e-commerce adoption show there is a positive but insignificant influence from the external environment on e-commerce adoption [7], but differed results show that the external environment had a significant positive influence on ecommerce adoption [17][20][19]. The study of the effect of e-commerce adoption on financial performance show results that e-commerce adoption affects the financial performance (means an increase in business income).

\section{Methodology}

The population is all MSMEs in Medan City, while the sample of this study is MSMEs that uses online media and uses Gojek's online transportation services as a means of selling. The total MSMEs population using Gojek services is 500 partners. The total sample was calculated using the Slovin formula with a 5\% error, so that a total sample of 222 respondents was obtained. This research variable consists of independent variables (X1) Organizational Readiness (KO), (X2) Technology Readiness (KT), (X3) External Environment (LE), moderation variable (Z) E-Commerce Adoption ( Ae-C) and dependent variable (Y) Improved financial performance (PK). Each variable will be measured using a Likert scale and given a score of one to seven.

\section{Results and Discussion}


Based on the results of the validity test using SPSS, it can be concluded that all questions to measure each research variable are declared valid. Reliability tests will use the facilities available in SPSS with the Cronbach Alpha $(\alpha)$ test [13]. A construct or variable is said to be reliable if it gives a Cronbach Alpha value> 0.70 Nunnally (1994) in [13]. Data processing results indicate that the construct of organizational readiness, technology readiness, external environment, e-commerce adoption, financial performance, all variables are reliable. Table 1 below shows the results of partial calculations ( $\mathrm{t}$ count) for the model above.

The effect of variable (X1) Organizational Readiness(OR), (X2) Technology Readiness (TR), (X3)External Environment (EE) on variable (Z) E-Commerce Adoption ( Ae-C), shown in the table 1 :

Table 1. Partial Test (1)

\begin{tabular}{cccccc}
\hline & $\begin{array}{c}\text { Unstandardized } \\
\boldsymbol{\beta}\end{array}$ & $\begin{array}{c}\text { Standardized } \\
\boldsymbol{\beta}\end{array}$ & $\mathbf{t}$ & Sig & Conclusion \\
\hline $\mathrm{C}$ & 18.190 & & 6.348 & .000 & \\
$\mathrm{X} 1$ & .282 & .165 & 2.078 & .040 & Significant influence \\
$\mathrm{X} 2$ & 1.060 & .591 & 7.373 & .000 & $\begin{array}{c}\text { Significant influence } \\
\text { Influence but not } \\
\text { X3 }\end{array}$ \\
\hline 141 & .136 & 1.946 & .054 & \\
\hline
\end{tabular}

The effect of variable (Z) E-Commerce Adoption ( Ae-C) on variable (Y) financial performance (FP), shown in the table 2:

Table 2. $\mathrm{T}$ test (2)

\begin{tabular}{cccccc}
\hline & $\begin{array}{c}\text { Unstandardized } \\
\boldsymbol{\beta}\end{array}$ & $\begin{array}{c}\text { Standardized } \\
\boldsymbol{\beta}\end{array}$ & $\mathbf{t}$ & $\mathbf{S i g}$ & Conclusion \\
\hline & 4.783 & & 2.324 & .022 & \\
$\mathrm{Z}$ & .469 & .756 & 11.766 & .000 & $\begin{array}{c}\text { Significant } \\
\text { influence }\end{array}$ \\
\hline
\end{tabular}

The results of data processing find the value of $\mathrm{R}$ Square for each variable. The organizational readiness variable (X1) has a value 0.304. This result means that the organizational readiness variable is able to explain the variation of e-commerce adoption, while organizational readiness has $\mathrm{R}^{2} 0.542$ which means that this variable is able to explain the variation of e-commerce adoption by $54.2 \%$ and the external environment is able to explain the variance of e-commerce adoption 0.169 which means that external environmental variables can explain the variation of e-commerce adoption by $16.9 \%$.

Table 3. Results of data processing

\begin{tabular}{cccccc}
\hline Explanation & $\mathbf{R}^{2}$ & $\mathbf{t}$ & $\mathbf{F}$ & Sig & Conclusion \\
\hline $\mathrm{X} 1 \rightarrow \mathrm{Y}$ & .304 & 2.078 & & .040 & Significant influence \\
$\mathrm{X} 2 \rightarrow \mathrm{Y}$ & .542 & 7.373 & & .000 & Significant influence \\
$\mathrm{X} 3 \rightarrow \mathrm{Y}$ & .169 & 1.946 & & .054 & Influence but not significant \\
$\mathrm{X} 1+\mathrm{X} 2+\mathrm{X} 3 \rightarrow \mathrm{Y}$ & .582 & & 38.199 & .000 & Significant influence \\
$\mathrm{Y}-\mathrm{Z}$ & .571 & 11.766 & & .000 & Significant influence \\
\hline
\end{tabular}

While $\mathrm{R}^{2}$ simultaneously shows a number of 0.582 or $58.2 \%$, this figure shows three independent variables consisting of organizational readiness, technology readiness and the external environment can explain variations in e-commerce adoption by $58.2 \%$, while $41.8 \%$ are explained by others variables outside this study. 


\subsection{The Effect of organizational readiness on e-commerce adoption}

The instrument statement from the questionnaire in this study led to the availability of corporate support for the transfer of sales from conventional methods to sales with online media support. Changing consumer behavior causes changes in culture in the organization, and changes in organizational culture are taken into consideration in every development and implementation of information systems in the company. The results of this study are in line with [14] who found the results of research on the interrelationship of organizational culture with the integration of information systems into the simplicity of business processes that caused companies to compete. The emergence of online-based transportation such as Gojek, Grab and others is also a strong reason for companies to use online media.

Table 4. analysis of instruments for statements of organizational readiness

\begin{tabular}{lccc}
\hline \multicolumn{1}{c}{ Statement } & Score & $\begin{array}{c}\text { Maximum } \\
\text { score }\end{array}$ \\
\hline Financial readiness & 595 & 742 & $80.19 \%$ \\
Readiness to risk & 594 & 742 & $80.05 \%$ \\
Commitment & 550 & 742 & $74.12 \%$ \\
Acceptance of technological development & 582 & 742 & $78.44 \%$ \\
\hline
\end{tabular}

According to data per indicator for organizational readiness, it can be seen that financial support has the strongest influence on e-commerce adoption, which is $80.19 \%$, this means that companies that adopt e-commerce are companies that support finance, followed by the readiness of the organization to bear the risk of e-commerce adoption is $80.05 \%$ while the organization's acceptance of technology development has an influence of $78.44 \%$, followed by an influential organizational commitment of $74.12 \%$.

In this study it can be seen that organizational readiness is one of the factors that influence e-commerce adoption. The results of this study support previous research [15] [16] [17] [4] [18][19], but the result of the study differed from several studies that found organizational factors have negative and insignificant effects [7][20].

\subsection{The Effect of technological readiness on e-commerce adoption.}

The question instrument of the questionnaire in this study leads to the availability of corporate support for the use of online-based technology to support the company's sales activities.

Table 5. Analysis of instruments for statements of technological readiness

\begin{tabular}{llccc}
\hline No & \multicolumn{1}{c}{ Statement } & Score & $\begin{array}{c}\text { Max. } \\
\text { Score }\end{array}$ & $\%$ \\
\hline 1 & HR is available in using Information Technology. & 595 & 742 & $80.19 \%$ \\
2 & Information technology tools available & 594 & 742 & $80.05 \%$ \\
3 & programs and e-commerce support systems available & 550 & 742 & $74.12 \%$ \\
4 & Company motivation on e-commerce adoption & 582 & 742 & $78.44 \%$ \\
\hline
\end{tabular}


Technology readiness in adopting e-commerce is a tool that pioneered sales and promotion applications using online technology-based applications to bring companies closer to consumers. According to data per indicator for technology readiness, it is seen that the availability of human resources (HR) who have the expertise and ability and mastery of information technology have the most powerful influence, namely $80.19 \%$. These results can mean that changes in technology must be supported also by the availability of skilled human resources, which means that if the company will adopt e-commerce within the company then the company must have human resources capable of using the application.

The next instrument that is quite dominant, of course, is the availability of information technology which is the main tool in adopting e-commerce. The instrument value of this question shows the number $80.05 \%$ followed by the availability of programs and support systems, e-commerce with a total score of $74.12 \%$. However, it is rather surprising that researchers should ask the question "the availability of information technology tools and ecommerce support systems and systems" will have the highest total scores given in ecommerce adoption, information technology tools, programs and support systems are very important. But the results of the study really put "the availability of trained human resources" to be the most influential indicator if the company will adopt e-commerce. While the final question instrument leads to company motivation when it comes to adopting e-commerce. For this indicator, the company's motivation is that the company hopes that the profits gained by getting closer to online consumers will be greater than the total cost. The total score for this question instrument is $78.44 \%$. Although companies realize that adopting e-commerce will require sufficient financial support to provide information technology, providing e-commerce support programs and systems, HR training, maintenance costs for hardware and software, but increasing benefits such as increasing sales, reducing promotional costs, service to consumers is maintained and others become a strong motivation for companies in adopting e-commerce. In this study it can be seen that technological readiness is one of the factors that influence ecommerce adoption. The results of this study support the findings of several research who find that technological readiness has a positive and significant impact on e-commerce adoption [12][7][21] [22].

\subsection{The Effect of External environmental on e-commerce adoption.}

Regarding environmental variables, to answer the hypothesis this variable is supported by 5 statement instruments in table 6 above which are external driving factors.

Table 6. Analysis of external environmental statement instruments

\begin{tabular}{llccc}
\hline No & \multicolumn{1}{c}{ Statement } & Score & $\begin{array}{l}\text { Max. } \\
\text { Score }\end{array}$ & \% \\
\hline 1 & Encouragement from consumers & 605 & 742 & 81.54 \\
\hline 2 & Encouragement from suppliers & 496 & 742 & 66.85 \\
\hline 3 & $\begin{array}{l}\text { Encouragement from the development of the business } \\
\text { world }\end{array}$ & 609 & 742 & 82.08 \\
\hline 4 & Encouragement from government or related institutions & 448 & 742 & 60.38 \\
\hline 5 & Encouragement from competitors & 580 & 742 & 78.17 \\
\hline
\end{tabular}

From the table 6 , it can be concluded that the main reason for being the main driving factor is the drive from the development of the business world itself, as expressed in the background where changes in consumer behavior patterns from personal shopping become online shopping. Consumers now prefer to interact with technology to shop rather than 
interact directly with sellers. This causes companies that want to keep consumers from turning to competitors who offer service convenience both from time and other selling purnal services, companies must keep abreast of current technology-based developments. Encouragement of encouraging instruments from business development has a total score of $82.08 \%$ followed by a total score of encouragement from consumers $81.54 \%$ and a total score of encouragement from competitors $78.17 \%$, this result can be interpreted that if the company does not want to lose its customers and turn to competitors who have adopted e-commerce and to improve performance through increasing sales and reducing promotional costs, companies must keep abreast of the business world by also adopting e-commerce. The next driving factor that was suspected by the researchers to be the reason why the influence of external environmental factors was insignificant, which came from a statement of encouragement from suppliers with a total score of only $66.85 \%$ followed by encouragement from the government and other institutions. with a total score of $60.38 \%$. The total score obtained by these two instruments shows that government and supplier factors, although influential, are not the main trigger factors that encourage companies to adopt e-commerce. In this study it can be seen that the external environment is also one of the factors that influence the adoption of e-commerce even though the effect is not significant. The results of this study are in line with Hanum \& Sinasari where there is a positive but insignificant influence from the external environment on ecommerce adoption [7], but the results of this study contradict the results from other researchs who found the results of the external environment had a significant positive influence on ecommerce adoption [17][20][19].

\subsection{The Effect of e-commerce adoption on financial performance}

The table below is a statement instrument used to answer hypotheses related to the influence of e-commerce adoption on financial performance.

Table 7. Analysis of e-commerce adoption statement instruments

\begin{tabular}{clcrc}
\hline No & \multicolumn{1}{c}{ Statement } & Score & Max. Score & \% \\
\hline 1 & Organization supports & 572 & 742 & 77.09 \\
\hline 2 & Resources available & 574 & 742 & 77.36 \\
\hline 3 & Information technology facilities and infrastructure & 577 & 742 & 77.76 \\
\hline 4 & Environment / outside party influence & 587 & 742 & 79.11 \\
\hline 5 & Facilitate access to required information & 625 & 742 & 84.23 \\
\hline 6 & Provides benefits to improve performance & 633 & 742 & 85.31 \\
\hline 7 & Improve quality and service speed & 629 & 742 & 84.77 \\
\hline 8 & Increase cost efficiency & 611 & 742 & 82.35 \\
\hline 9 & Getting more benefits than conventional methods & 613 & 742 & 82.61 \\
\hline
\end{tabular}

The main reason that influences e-commerce adoption is because companies believe that e-commerce adoption will provide benefits in improving performance. This question instrument has a total score of $85.31 \%$ from other random successions which greatly affects the company's reason for improving performance because according to e-commerce adoption companies will improve service quality and speed (84.77\%), facilitate access to the information needed $(84,23 \%)$, the perception that online companies will benefit more than conventional trading methods $(82.61 \%)$, the company's perception that with the application of e-commerce can increase cost efficiency (82.35\%). Expected cost efficiency such as information search cost efficiency, communication costs, promotion costs and product marketing costs. 
Questions 5 to 9 instrument items are items that are directly related to performance, while items 1 to 4 are information related to reasons for support for the company if they want to improve performance by utilizing e-commerce. This supporting reason means that if the company wants to improve financial performance, there must be organizational support for ecommerce use $(77.09 \%)$, providing trained human resources $(77.36 \%)$, providing adequate facilities and infrastructure $(77,76 \%)$ and of course the company's efforts to improve their financial performance are influences from the external and internal environment $(79.11 \%)$. In this study it can be seen that the external environment is also one of the factors that influence e-commerce adoption. This finding is in line with other research who also found that ecommerce adoption affects performance [19][7][22].

\section{Conclusion}

Research shows that organizational partial readiness has a positive and significant influence on e-commerce adoption, technology readiness partially has a positive and significant influence on e-commerce adoption. The external environment partially does not have a significant positive influence on e-commerce implementation and e-commerce adoption partially has a positive and significant impact on performance. This research still has limitations, one of which is a sample collected around 50\%. This is due to limited study time and some MSMEs refuse to complete the questionnaire on the grounds that they do not want to provide information about their business. $\mathrm{R}^{2}$ value $58.2 \%$ shows that there are other variables that influence e-commerce adoption and financial performance.

\section{References}

[1] I. Widiyanto and S. L. Prasilowati, "Perilaku pembelian melalui internet," vol. 17, no. 2, pp. 109-112, 2015.

[2] A. Nurrohmah and F. Alfanur, "Adopsi E-Commerce Pada Usaha Mikro Dan Kecil Di Bandung ( Studi Kasus Subsektor Fesyen ) Adoption of E-Commerce on Micro and Small Enterprise in Bandung ( Fashion Subsector Case Study )," in e-Proceeding of Management, 2016, vol. 3, no. 2, pp. 1120-1127.

[3] R. Rahayu and J. Day, "Determinant Factors of E-commerce Adoption by SMEs in Developing Country: Evidence from Indonesia," Procedia - Soc. Behav. Sci., vol. 195, pp. 142-150, 2015.

[4] R. Rahayu and J. Day, "E-commerce adoption by SMEs in developing countries: evidence from Indonesia," Eurasian Bus. Rev., vol. 7, no. 1, pp. 25-41, 2017.

[5] Noerlina and S. E. Hiererra, "Penilaian Pemanfaat Teknologi E-Business Pada Industri UMKM," ComTech, vol. 4, no. 9, pp. 1216-1224, 2013.

[6] H. Magdalena, "Strategi Memanfaatkan E-Commerce Dalam Memasarkan Makanan Khas Bangka ( Studi Kasus: Aneka Citra Snack ) The Strategy of Exploiting E-Commerce in The Marketing Of Bangka Peculiar Food ( Case Study: Aneka Citra Snack )," Cogito Smart J., vol. VOL. 3, no. NO. 2/DEC 2017, pp. 286-298, 2017.

[7] A. N. Hanum and A. Sinarasri, "Analisis faktor-faktor yang mempengaruhi adopsi e commerce dan pengaruhnya terhadap kinerja umkm (studi kasus umkm di wilayah kota semarang)," Maksimum, vol. Vol. 1, no. No. 1, pp. 1-15, 2017.

[8] S. Kabanda and I. Brown, "A structuration analysis of Small and Medium Enterprise (SME) adoption of E-Commerce: The case of Tanzania," Telemat. Informatics, vol. 34, no. 4, pp. 118 $132,2017$. 
[9] S. C. Lim, A. S. Baharudin, and R. Q. Low, "Factors Influence SMEs in Malaysia to Adopt eCommerce: Moderating Roles of Perceived Strategic Value," J. Eng. Appl. Sci., vol. 12, no. 6, pp. 1566-1574, 2017.

[10] M. Iqbal and R. D. Astuti, “Analisis Faktor Yang Memperngaruhi Pengadopsian E-Commerce Pada UMKM Khususnya Bisnis Keluarga," 2013.

[11] Fatmariani, "Pengaruh Adopsi Teknologi Informasi Open Source E-Commerce Terhadap Kinerja UKM Dengan Faktor-Faktor Technology Acceptance Model (TAM) Sebagai Moderating Variable," J. Teknol. dan Inform., vol. 1, no. 1, pp. 70-83, 2011.

[12] I. H. Napitupulu and A. Situngkir, "Integrated Management Accounting Information System for Competitive Adventage: The Case in State -Owned Enterprises of Indonesia," Int. Bus. Manag., vol. 10, no. 23, pp. 5643-5650, 2016.

[13] I. Ghozali, Aplikasi Analisis Multivariate Dengan Program IBM SPSS 23, VIII. Semarang: Badan Penerbit Universitas Diponegoro., 2016.

[14] I. H. Napitupulu, "Accounting Information System : ot fo r c om m er c ia $1 \mathrm{u}$ se ot fo Review of Literature om m c 1 u," Glob. Bus. Rev., vol. 19, no. 3, pp. 556-571, 2018.

[15] M. F. Oliveira, T., \& Martins, "Literature review of information technology adoption models at firm level," Electron. J. Inf. Syst. Eval., vol. 14, no. 14(1), p. pp 110-121., 2011.

[16] J. Martínez-Ferrero, "Consequences of financial reporting quality on corporate performance. Evidence at the international level," Estud. Econ., vol. 41, no. ii, pp. 49-88, 2014.

[17] X. Duan, H. Deng, and B. Corbitt, "Evaluating the critical determinants for adopting e-market in Australian small-and-medium sized enterprises," Manag. Res. Rev., vol. 35, no. 3-4, pp. 289 308, 2012.

[18] V. A. Yulimar, "Analisis Faktor-Faktor Yang Mempengaruhi Pengadopsian Electronic Commerce Dan Pengaruhnya Terhadap Kinerja Perusahaan ( Studi Pada Perusahaan Kecil Dan Menengah Di Indonesia )," 2010.

[19] V. A. Yulimar, "Analisis Faktor-Faktor Yang Mempegaruhi Pengadopsian Electronic Commerce Dan Pengaruhnya Terhadap Kinerja Perusahaan (Studi Pada Perusahaan Kecil dan Menengah Di Indonesia)," in Seminar Nasional Aplikasi Sains dan Teknologi 2008, 2008, pp. $118-128$.

[20] P. K. Ningtyas and B. Sunarko, "Analisis Faktor Yang Mempengaruhi Adopsi E-Commerce Dan Pengaruhnya Terhadap Kinerja UMKM," Peformance, vol. 21, no. 1, pp. 95-107, 2011.

[21] T. Oliveira and M. F. Martins, "Understanding e-business adoption across industries in European countries," Ind. Manag. Data Syst., vol. 110, no. 9, pp. 1337-1354, 2010.

[22] M. Sholihin and S. Mujilahwati, "Dampak Pemanfaatan E-Commerce Terhadap Peningkatan Penjualan di UMKM ( Studi Kasus Ninda Bros Lamongan ),” J. Tek., vol. 8, no. 1, 2016. 